\title{
Adhesion and biofilm formation by Staphylococcus aureus from food processing plants as affected by growth medium, surface type and incubation temperature
}

\author{
Heloísa Maria Ângelo Jerônimo, Rita de Cássia Ramos do Egypto Queiroga, Ana Caroliny Vieira \\ da Costa, Isabella de Medeiros Barbosa, Maria Lúcia da Conceição, Evandro Leite de Souza*
}

\author{
Laboratory of Food Microbiology, Department of Nutrition, Health Sciences Center, Federal University of Paraiba
}

\begin{abstract}
This study assessed the effect of different growth media [BHI broth, BHI broth plus glucose $(10 \mathrm{~g} / 100$ $\mathrm{mL})$ and $\mathrm{BHI}$ broth plus $\mathrm{NaCl}(5 \mathrm{~g} / 100 \mathrm{~mL})]$ and incubation temperatures $\left(28\right.$ or $\left.37^{\circ} \mathrm{C}\right)$ on the adherence, detachment and biofilm formation on polypropylene and stainless steel surfaces ( 2 x $2 \mathrm{~cm}$ coupons $)$ for a prolonged period (24-72 h) by some strains of Staphylococcus aureus (S3, S28 and S54) from food processing plants. The efficacy of the sanitizers sodium hypochlorite $(250 \mathrm{mg} / \mathrm{mL})$ and peracetic acid $(30 \mathrm{mg} / \mathrm{mL})$ in reducing the number of viable bacterial cells in a preformed biofilm was also evaluated. $S$. aureus strains adhered in highest numbers in BHI broth, regardless of the type of surface or incubation temperature. Cell detachment from surfaces revealed high persistence over the incubation period. The number of cells needed for biofilm formation was noted in all experimental systems after 3 days. Peracetic acid and sodium hypochlorite were not efficient in completely removing the cells of $S$. aureus adhered onto polypropylene and stainless steel surfaces. From these results, the assayed strains revealed high capacities to adhere and form biofilms on polypropylene and stainless steel surfaces under the different growth conditions, and the cells in biofilm matrixes were resistant to total removal when exposed to the sanitizers sodium hypochlorite and peracetic acid.
\end{abstract}

Uniterms: Staphylococcus aureus/food processing. Biofilm. Surfaces. Sanitizers/efficacy.

Este estudo teve como objetivo avaliar o efeito de diferentes meios de crescimento [caldo BHI, caldo $\mathrm{BHI}$ adicionado de glucose $(10 \mathrm{~g} / 100 \mathrm{~mL})$ e caldo $\mathrm{BHI}$ adicionado de $\mathrm{NaCl}(5 \mathrm{~g} / 100 \mathrm{~mL})]$ e temperaturas de incubação $\left(28\right.$ e $\left.37^{\circ} \mathrm{C}\right)$ sobre a adesão, separação e formação de biofilme sobre superfícies $(2$ × 2 $\mathrm{cm})$ de polipropileno e aço inoxidável durante longo tempo de incubação $(24-72 \mathrm{~h}$ ) por parte de cepas de Staphylococcus aureus (S3, S58 e S54) isoladas de plantas de processamento de alimentos. Também foi avaliada a eficácia dos sanitizantes hipoclorito de sódio $(250 \mathrm{mg} / \mathrm{mL})$ e ácido peracético $(30 \mathrm{mg} / \mathrm{mL})$ na redução do número de células bacterianas viáveis presentes em um biofilme pré-formado. As cepas de $S$. aureus aderiram em número mais elevado quando incubadas em caldo BHI em ambos os tipos de superfícies e temperaturas de incubação testadas. A separação das células das superfícies revelou alta persistência ao longo do período de incubação. Número de células necessário para a formação do biofilme foi detectado depois de três dias de incubação em todos os sistemas experimentais. O ácido peracético e o hipoclorito de sódio não foram eficientes em remover completamente a células de $S$. aureus aderidas sobre as superfícies de polipropileno e aço inoxidável. Os resultados obtidos revelaram alta capacidade das cepas ensaiadas em aderir e formar biofilme sobre superfícies de polipropileno e aço inoxidável sobre diferentes condições de crescimento e que as células na matriz do biofilme apresentaram-se resistentes à total remoção quando expostas aos sanitizantes hipoclorito de sódio e ácido peracético.

Unitermos: Staphylococcus aureus/ processamento de alimentos. Adesão. Superfícies. Biofilme. Sanitizantes/eficácia.

*Correspondence: E.L. Souza. Departamento de Nutrição, Centro de Ciências da Saúde, Universidade Federal da Paraíba, Campus I, Cidade Universitária, 58051-900 - João Pessoa - PB, Brasil. E-mail: evandroleitesouza@ccs.ufpb.br 


\section{INTRODUCTION}

The relevance of contaminated surfaces in spreading pathogenic microorganisms to foods is already well established for food processing plants (Kusumaningru et al., 2003; Fuster-Valls et al., 2008). Some pathogenic bacteria are able to adhere to food-contact surfaces and remain viable even after cleaning and disinfection (Ammor et al., 2004). One of the most common ways for bacteria to live is adhering to surfaces and forming biofilms in which they are embedded in an organic, extracellular polymeric matrix (Chae, Schraft, 2000).

Biofilm-adhered bacteria can detach during processing and contaminate food as it passes the surfaces. This cross-contamination is a high-risk source of pathogenic bacteria and may seriously affect the safety and quality of foods (Bagge-Ravn et al., 2003).

Staphylococcus aureus is among the most common pathogenic bacteria isolated from surfaces in food processing plants (Pastoriza et al., 2002), where it can adhere and form biofilms (Kunig, Almeida, 2001). Foodborne disease caused by $S$. aureus is typically intoxication due to the ingestion of enterotoxins preformed in food by enterotoxigenic strains (Normanno et al., 2007). Most investigations regarding biofilm formation by staphylococci using $S$. epidermidis as the model microorganism have focused on clinical aspects in association with implants and medical devices (Rode et al., 2007). Whereas the capacity for adhesion and biofilm formation of some food-related pathogenic bacteria has already been elucidated (Conlon et al., 2002), studies focusing on the adhesion and biofilm formation of $S$. aureus are still rare. Regarding these aspects, it is important to identify the conditions under which $S$. aureus is able to survive and multiply on food processing surfaces. Early studies found that bacterial adhesion and biofilm formation depended upon the bacterial species, the nature of the surface, the growth medium and other environmental conditions (Pompermayer, Gaylarde, 2007).

The present study aimed to evaluate the capability of strains of $S$. aureus from surfaces of food processing plants to adhere and form biofilms on polypropylene and stainless steel surfaces when exposed to different growth media and incubation temperatures. The study also assessed the effects of the sanitizers peracetic acid and sodium hypochlorite in reducing the number of viable bacterial cells in a preformed biofilm.

\section{MATERIAL AND METHODS}

\section{Test strains}

S. aureus S3, S. aureus S28 and S. aureus S54 ob- tained from the Microorganism Collection, Laboratory of Food Microbiology, Health Sciences Center, Federal University of Paraíba (João Pessoa, Brazil), were used as test microorganisms. These strains were isolated from different surfaces of Food Processing Plants using standard procedures. Stock cultures were kept on Nutrient Agar (NA) (Difco, Brazil) slants under refrigeration $\left(7 \pm 1{ }^{\circ} \mathrm{C}\right)$.

Unless otherwise stated, inocula $(10 \log \mathrm{cfu} / \mathrm{mL})$ used in assays were obtained from suspensions of the strains in the stationary phase of growth and prepared following a previously described procedure (Carson et al., 2002). The suspensions obtained were serially diluted in PBS $\left(10^{-1}-10^{-2}\right)$ to provide a viable cell count of approximately $8.0 \log \mathrm{cfu} / \mathrm{mL}$.

\section{Surfaces}

AISI 304 stainless steel $(2 \times 2 \times 0.2 \mathrm{~cm})$ and polypropylene coupons $(2 \times 2 \times 0.4 \mathrm{~cm})$ were used as test surfaces. The coupons were individually cleaned, sanitized and sterilized according to a previously described procedure (Marques et al., 2007).

\section{Experimental conditions}

The adherence, detachment and biofilm formation of the test strains were assessed under six different experimental conditions: i) in the presence of a nutrientrich medium using Brain Heart Infusion Broth (BHI) at $28^{\circ} \mathrm{C}$; ii) in the presence of a nutrient-rich medium (BHI) at $37^{\circ} \mathrm{C}$; iii) in the presence of a nutrient-rich and adhesion-promoting medium, BHI supplemented with $10 \mathrm{~g} / \mathrm{L}$ of glucose (BHI-Glucose) at $28{ }^{\circ} \mathrm{C}$; iv) in the presence of a nutrient-rich and adhesion-promoting medium (BHI-Glucose) at $37^{\circ} \mathrm{C}$; v) in the presence of a selective medium, BHI supplemented with $5 \mathrm{~g} / \mathrm{L}$ of $\mathrm{NaCl}$ (BHI-NaCl) at $28^{\circ} \mathrm{C}$; and vi) in the presence of a selective medium (BHI- $\mathrm{NaCl}$ ) at $37^{\circ} \mathrm{C}$.

\section{Adhesion to surfaces and quantification of adhered cells}

An aliquot of $100 \mu \mathrm{L}$ of the growth media was mixed with $50 \mu \mathrm{L}$ of the bacterial inoculum, plated onto the center of each coupon and incubated under the pre-established temperatures. After 24, 48 and $72 \mathrm{~h}$ of incubation, coupons (two for each treatment) were withdrawn and immersed in sterile peptone water (SPW) $(0.1 \mathrm{~g} / 100 \mathrm{~mL})$ for $15 \mathrm{~s}$ to release non-adhered cells. The cells adhered to the coupons were collected by thoroughly rubbing their surfaces with two moistened swabs, and the cells were resuspended in 
SPW with vigorous vortexing for $30 \mathrm{~s}$. The mixture was serially diluted $\left(10^{-1}-10^{-5}\right)$ in SPW, and aliquots of $100 \mu \mathrm{L}$ were spread plated onto sterile NA plates. The plates were incubated for $24 \mathrm{~h}$ at $37^{\circ} \mathrm{C}$ (Herrera et al., 2007; Rode et al., 2007). After the incubation period, the number of viable cells was counted, and the results were expressed as $\log \mathrm{cfu} / \mathrm{cm}^{2}$.

\section{Detachment of adhered cells}

An aliquot of $100 \mu \mathrm{L}$ of the growth media was mixed with $50 \mu \mathrm{L}$ of the bacterial inoculum and plated onto the center of each coupon, followed by incubation under the pre-established temperatures. After 24, 48 and $72 \mathrm{~h}$ of incubation, coupons (two for each treatment) were withdrawn and immersed in SPW for $15 \mathrm{~s}$ to release nonadhered cells. Each coupon was placed onto a sterile NA plate, and after $2 \mathrm{~min}$, removed and placed onto a second sterile NA plate. This procedure was repeated through 7 sterile NA plates. The number of detached cells on the NA plates with order number of 1, 2, 3, 4, 5, 6 and 7 was found by transferring the agar blotting from each plate to $10 \mathrm{~mL}$ of SPW followed by blending using a Stomacher. The mixture was serially diluted $\left(10^{-1}-10^{-5}\right)$ in SPW, and aliquots of $100 \mu \mathrm{L}$ were spread plated onto NA plates. The plates were incubated for $24 \mathrm{~h}$ at $37^{\circ} \mathrm{C}$ (Herrera et al., 2007). After the incubation period, the number of viable cells was counted and the results expressed in Log cfu $/ \mathrm{cm}^{2}$.

\section{Biofilm development and quantification}

The level of biofilm formation by $S$. aureus $\mathrm{S} 3$ on polypropylene and stainless steel surfaces incubated in vegetable broth at $7^{\circ} \mathrm{C}$ and $28^{\circ} \mathrm{C}$ over 15 days was assessed. For this measurement, five stainless and five polypropylene coupons were immersed in sterile Petri dishes containing 20 $\mathrm{mL}$ of the growth media and $2 \mathrm{~mL}$ of the bacterial inoculum. The Petri dishes were sealed and incubated statically at the pre-established temperatures. After 3, 6, 9, 12 and 15 days of incubation, the coupons were withdrawn and washed with SPW to remove the non-adherent cells. Once again, the coupons were immersed in a fresh medium containing the same amount of inoculum, and the process was repeated four times over a 15-day period.

At each incubation interval, two coupons from each treatment were submitted to biofilm matrix bacterial counting. For this counting, each biofilm was scraped with two moistened sterile swabs and resuspended in $9 \mathrm{~mL}$ of SPW with vortexing for $30 \mathrm{~s}$. Serial dilutions were prepared in SPW, and aliquots of $100 \mu \mathrm{L}$ were spread plated onto sterile NA plates followed by incubation at $37^{\circ} \mathrm{C}$ for
$24 \mathrm{~h}$ (Marques et al., 2007). After the incubation period, the number of viable cells was counted and the results expressed as $\log \mathrm{cfu} / \mathrm{cm}^{2}$.

\section{Sanitizer application}

The efficacies of the sanitizers sodium hypochlorite $(250 \mathrm{mg} / \mathrm{L})$ and peracetic acid $(30 \mathrm{mg} / \mathrm{L})$ (Meira et al., 2012 ) in removing the cells of $S$. aureus $\mathrm{S} 3$ from the biofilm matrix grown in the vegetable-based broth at 7 and 28 ${ }^{\circ} \mathrm{C}$ were assessed. For this assessment, five coupons were allowed to develop biofilms according to the experimental conditions cited above. After 15 days of incubation, the coupons were washed in SPW and immersed for 30 $\mathrm{s}$ in sterile Petri dishes containing $20 \mathrm{~mL}$ of the sanitizer solution. Afterwards, the coupons were withdrawn from the sanitizer solution and immersed for $3 \mathrm{~s}$ in a neutralizing solution $\left(0.1 \mathrm{M} \mathrm{Na}_{2} \mathrm{~S}_{2} \mathrm{O}_{3}\right)$. The remaining cells were counted after scraping with two sterile moistened swabs and resuspended by vigorously vortexing in $9 \mathrm{~mL}$ of SPW. Serial dilutions were prepared in SPW, and aliquots of 100 $\mu \mathrm{L}$ were spread plated onto NA plates and incubated at 37 ${ }^{\circ} \mathrm{C}$ for $24 \mathrm{~h}$ (Ammor et al., 2004). After the incubation period, the number of viable cells was counted and the results expressed as Log $\mathrm{cfu} / \mathrm{cm}^{2}$. In control assays, the sanitizer solutions were replaced by sterile distilled water. The efficiency of each sanitizer was calculated as the difference between the counts obtained for the control surfaces and for the surfaces exposed to the sanitizers.

\section{Reproducibility and statistical analysis}

All analyses were carried out in triplicate, and the results are expressed as the average of the assays. Counts were converted to decimal Logarithmic values (Log cfu/ $\mathrm{cm}^{2}$ ) to nearly match the assumption of a normal distribution. Counts obtained for adhesion, detachment and biofilm formation were submitted to Analysis of Variance (ANOVA) followed by the Duncan test to determine the significance of the influences of the incubation temperatures and contact surfaces. Counts obtained for tests of the effects of the sanitizers (before and after the application) on the biofilm matrix were compared using the paired Student's t-test. Data were analyzed using the software Statistica 7. A probability value $P<0.05$ was accepted as indicating significant differences (Meira et al., 2012).

\section{RESULTS AND DISCUSSION}

As substrate and extrinsic characteristics have been reported to influence bacterial adherence, different 
growth media (nutrient rich-media, with or without added glucose and $\mathrm{NaCl})$ and incubation temperatures $(28$ and $37^{\circ} \mathrm{C}$ ) were tested to determine their possible influences on cell adherence and biofilm formation by isolates of $S$. aureus on polypropylene and stainless steel surfaces. The temperatures $37^{\circ} \mathrm{C}$ and $28{ }^{\circ} \mathrm{C}$ were chosen as the ideal temperature for the growth of S. aureus and the common environmental temperature found in Brazilian Food and Nutrition Services, respectively.

The numbers of $S$. aureus cells adhered to polypropylene and stainless steel surfaces under different experimental conditions over $72 \mathrm{~h}$ of incubation are shown in Figures 1-3. The highest numbers of adhered cells $\left(6-8 \log \mathrm{cfu} / \mathrm{cm}^{2}\right)$ on polypropylene and stainless steel surfaces were found when the strains were cultivated in BHI. There was no indication that adherence increased in $\mathrm{BHI}-\mathrm{NaCl}$ or BHI-Glucose media. It appears surprising that the presence of glucose and $\mathrm{NaCl}$ in the growth media caused no increase in the adhesion capacity of the assayed strains. Moretro et al. (2003) found that the presence of $\mathrm{NaCl}(2 \mathrm{~g} / 100 \mathrm{~mL})$ in tryptic soy broth (TSB) resulted in increased adhesion and biofilm formation by standard cultures of staphylococci from food and food processing environments. Herrera et al. (2007) also noted the same behavior for a standard culture of $S$. aureus cultured in TSB supplemented with glucose $(1 \mathrm{~g} / 100 \mathrm{~mL})$.

S. aureus $\mathrm{S} 3$ and $\mathrm{S} 54$ cultured in BHI at both tested temperatures revealed a clear two-phase adhesion pattern regardless of the surface type: an initial phase with a progressively increasing numbers of adhered cells, with highest counts after $48 \mathrm{~h}$ of incubation, followed by a second phase $(72 \mathrm{~h}$ ) with a decreasing number of adhered cells. These results suggest that under static conditions, the adhered cells may be present in high numbers, but the number of adhered cells do not constantly increase over the incubation time.

S. aureus S54 presented a different pattern of adhesion in most experimental systems, with a decrease in the numbers of adhered cells over the evaluated time intervals at 28 and $37^{\circ} \mathrm{C}$. Data for the number of adhered cells on stainless steel and polypropylene surfaces did not differ $(P>0.05)$ for strains S3 and S28 in all cultivation media at $37{ }^{\circ} \mathrm{C}$. For strain $\mathrm{S} 54$, there were greater numbers $(P<$ $0.05)$ of adhered cells on stainless steel surfaces than on polypropylene in BHI and BHI-glucose.

Regarding the effect of the incubation temperature on the adherence capability of the tested strains, it was surprising to note that no difference $(P>0.05)$ was found between $28{ }^{\circ} \mathrm{C}$ and $37^{\circ} \mathrm{C}$. Some previous studies have reported a positive effect of lower temperature on the adhesion pattern of S. aureus. Herald and Zottola (1988) noted that Listeria monocytogenes and Yersinia enterocolitica cultivated in laboratorial media adhered to stainless surfaces in greater numbers at $21^{\circ} \mathrm{C}$ than at $30^{\circ} \mathrm{C}$. Rode et al. (2007) found higher attachment capacity for $S$. aureus on polystyrene when cultivated in tryptic soy broth at sub-optimal temperatures $\left(20,25\right.$ and $\left.30^{\circ} \mathrm{C}\right)$. Morton et al. (1998) reported that regardless of the species or surface assayed, the adhesion process occurs at maximum intensity when microorganisms are allowed to grow at their optimum temperatures.

Among the tested strains, S. aureus S3 was used for
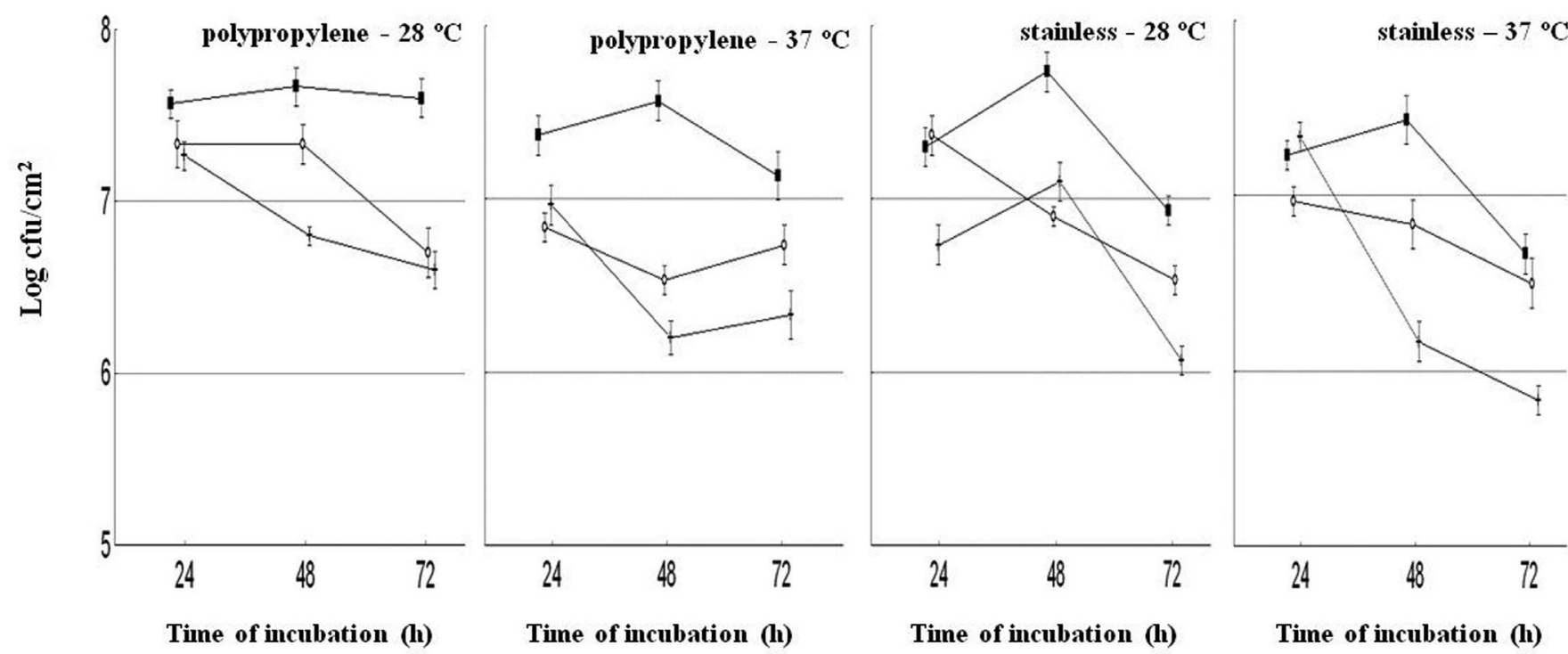

FIGURE 1 - Adhesion of $S$. aureus $\mathrm{S} 3$ to polypropylene and stainless steel surfaces as affected by different experimental conditions (a: BHI; $\diamond:$ BHI-Glucose; +: BHI-NaCl) over $72 \mathrm{~h}$ of incubation. 


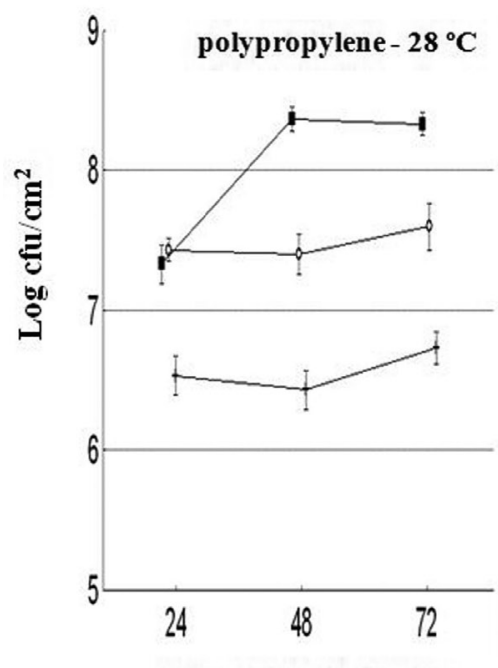

Time of incubation (h)

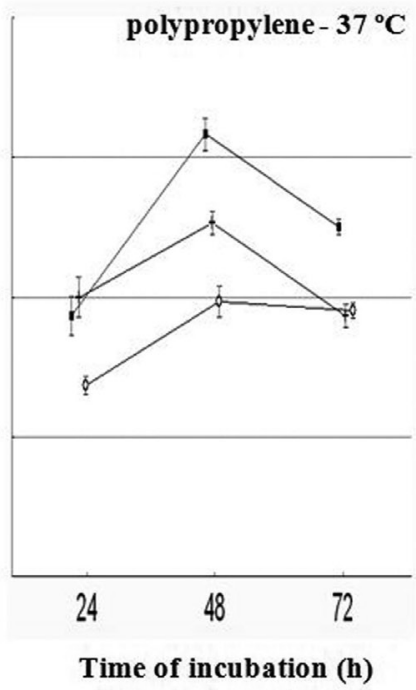

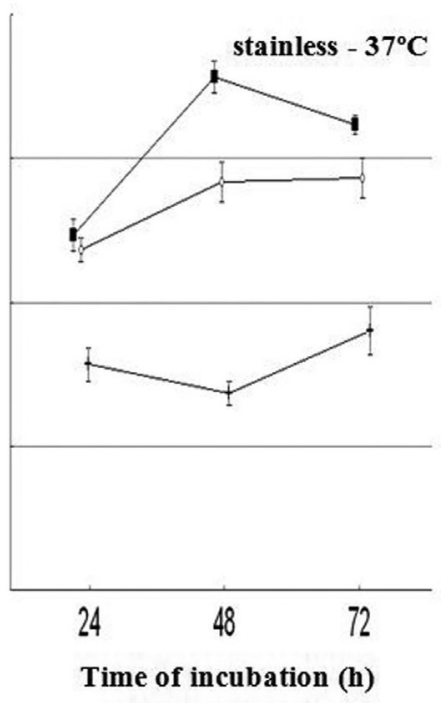

FIGURE 2 - Adhesion of $S$. aureus S28 to polypropylene and stainless steel surfaces as affected by different experimental conditions (n: BHI; $\diamond$ : BHI-Glucose; +: BHI-NaCl) over $72 \mathrm{~h}$ of incubation.

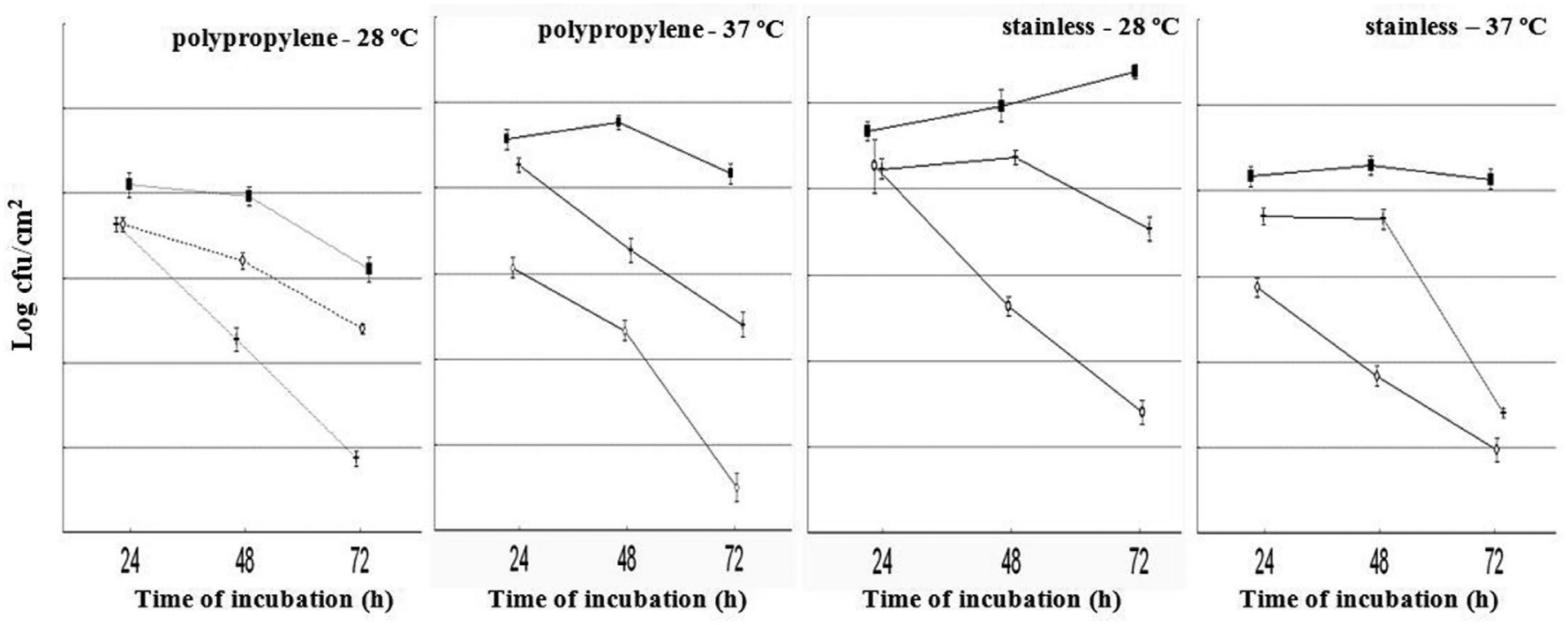

FIGURE 3 - Adhesion of $S$. aureus S54 to polypropylene and stainless steel surfaces as affected by different experimental conditions (匹: BHI; $\diamond:$ BHI-Glucose; +: BHI-NaCl) over $72 \mathrm{~h}$ of incubation.

further assays of detachment and biofilm formation. Data for cell detachment from polypropylene and stainless steel surfaces for $S$. aureus S3 under different experimental conditions are shown in Figures 4 and 5, respectively. Bacterial counts revealed a linear decrease in the detachment rate over the contact sequence for all experimental systems. Regarding the influence of the growth media, the results obtained showed higher detachment values $(P$ $<0.05)$ when the strain was grown in BHI compared to other media. In all experimental systems, the cell detachment was at least $3 \mathrm{Log} \mathrm{cfu} / \mathrm{cm}^{2}$ during the first 5 contacts (blots), suggesting high persistence of cells on the surfaces over $72 \mathrm{~h}$. No significant influence $(P>0.05)$ of the surface type or time of incubation was noted on the detachment rate. The highest numbers of detached cells were observed when $S$. aureus S3 was incubated in BHI, which could be related to increased bacterial growth on this substrate relative to the other growth media. These data about the detachment of cells over a large number of contacts with blot agar reveal a high risk of dissemination for $S$. aureus in food processing plants.

Levels of biofilm formation by $S$. aureus $\mathrm{S} 3$ on polypropylene and stainless surfaces over 15 days under different experimental conditions were also evaluated. For most systems, the number of cells in the biofilm matrix followed a linear decrease over the assayed incubation 

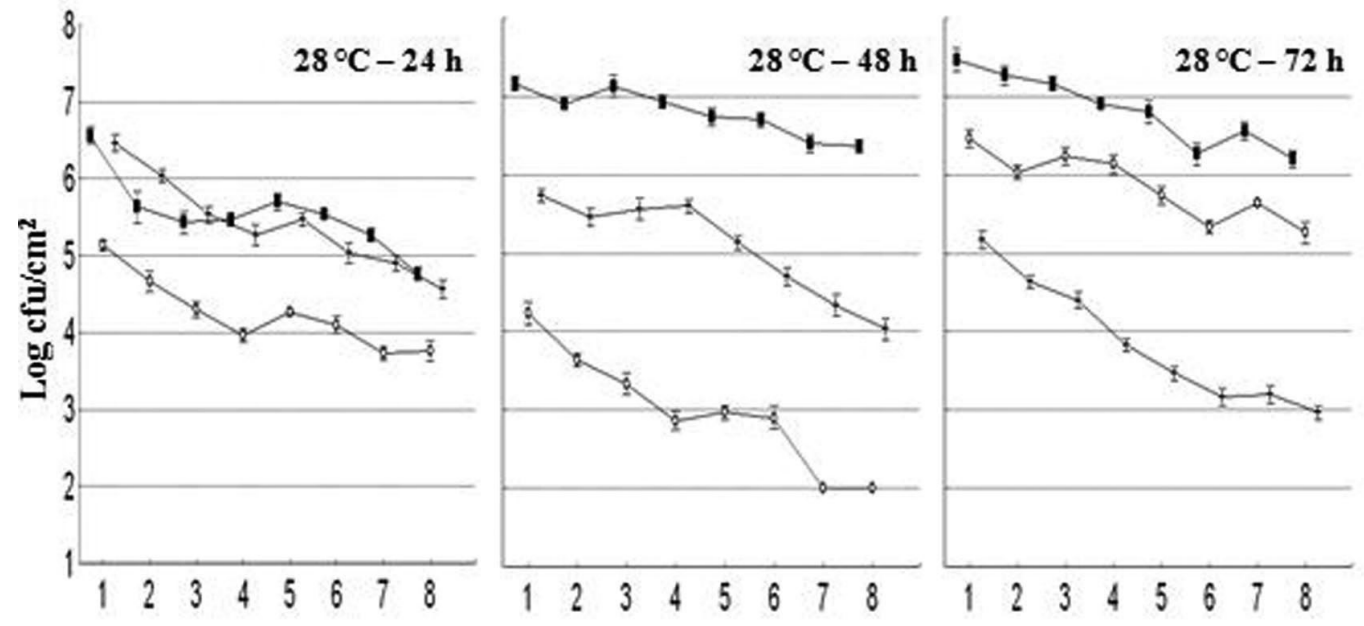

Transferring order
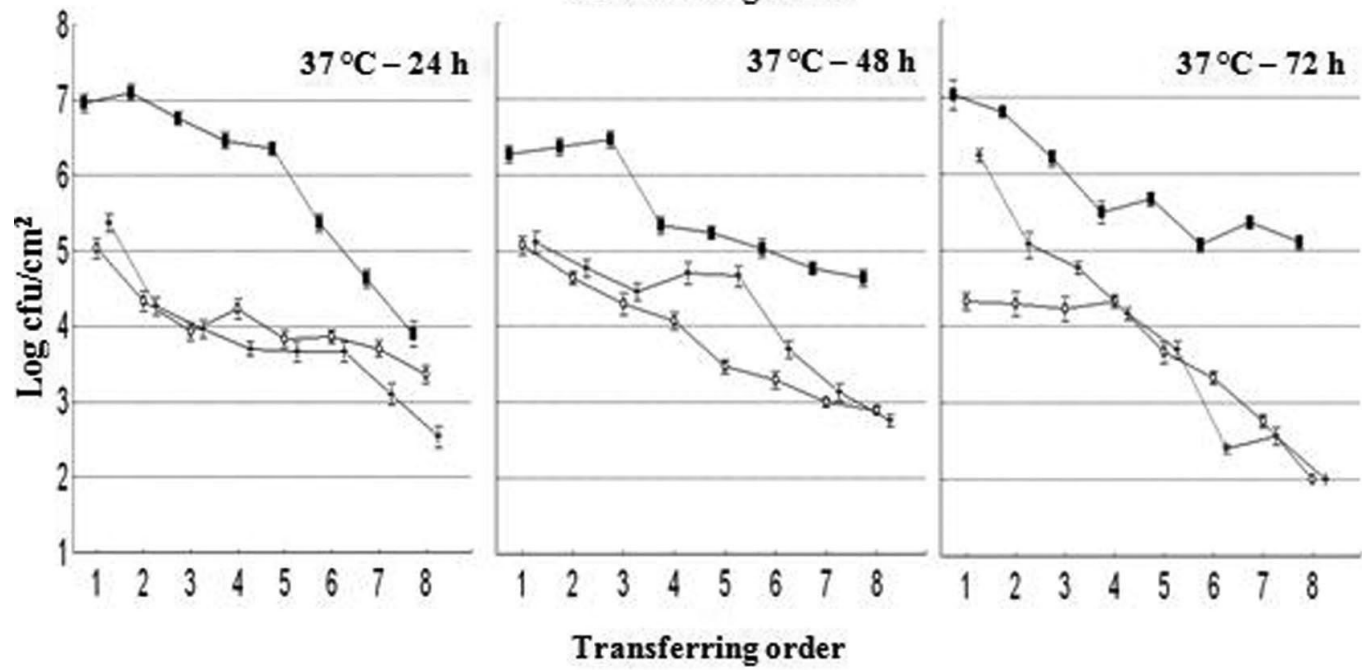

FIGURE 4 - Detachment of $S$. aureus $\mathrm{S} 3$ of polypropylene surfaces as affected by different experimental conditions ( $\mathbf{a}$ : BHI; $\diamond:$ BHI-Glucose; +: $\mathrm{BHI}-\mathrm{NaCl})$.

TABLE I - Effect of peracetic acid (30 mg/L) and sodium hypochlorite $(250 \mathrm{mg} / \mathrm{L})$ on counts (Log cfu/ $\left.\mathrm{cm}^{2}\right)$ of $S$. aureus $\mathrm{S} 3(\mathrm{grown}$ in BHI broth at 28 and $37^{\circ} \mathrm{C}$ ) adhered to polypropylene and stainless surfaces

\begin{tabular}{lcccc}
\hline Sanitizer & Temperature $\left({ }^{\circ} \mathrm{C}\right)$ & Control & Treated & Fraction reduced \\
\hline Polypropylene & & & & \\
\multicolumn{1}{c}{ Peracetic acid } & 28 & $7.3( \pm 0.3)^{\mathrm{a}}$ & $3.8( \pm 0.2)^{\mathrm{b}}$ & 3.5 \\
Sodium hypochlorite & 37 & $7.4( \pm 0.3)^{\mathrm{a}}$ & $3.3( \pm 0.2)^{\mathrm{b}}$ & 4.1 \\
Stainless steel & 28 & $7.1( \pm 0.4)^{\mathrm{a}}$ & $2.7( \pm 0.3)^{\mathrm{b}}$ & 4.4 \\
$\quad$ Peracetic acid & 37 & $7.4( \pm 0.4)^{\mathrm{a}}$ & $2.6( \pm 0.3)^{\mathrm{b}}$ & 4.8 \\
& & & & 2.8 \\
Sodium hypochlorite & 28 & $6.9( \pm 0.2)^{\mathrm{a}}$ & $4.1( \pm 0.2)^{\mathrm{b}}$ & 3.6 \\
& 28 & $7.7( \pm 0.2)^{\mathrm{a}}$ & $4.2( \pm 0.4)^{\mathrm{b}}$ & 4.3 \\
\hline
\end{tabular}

Values followed by the same letters in each line differ significantly $(\mathrm{p}<0.05)$ according to the Student $\mathrm{t}$ test. 

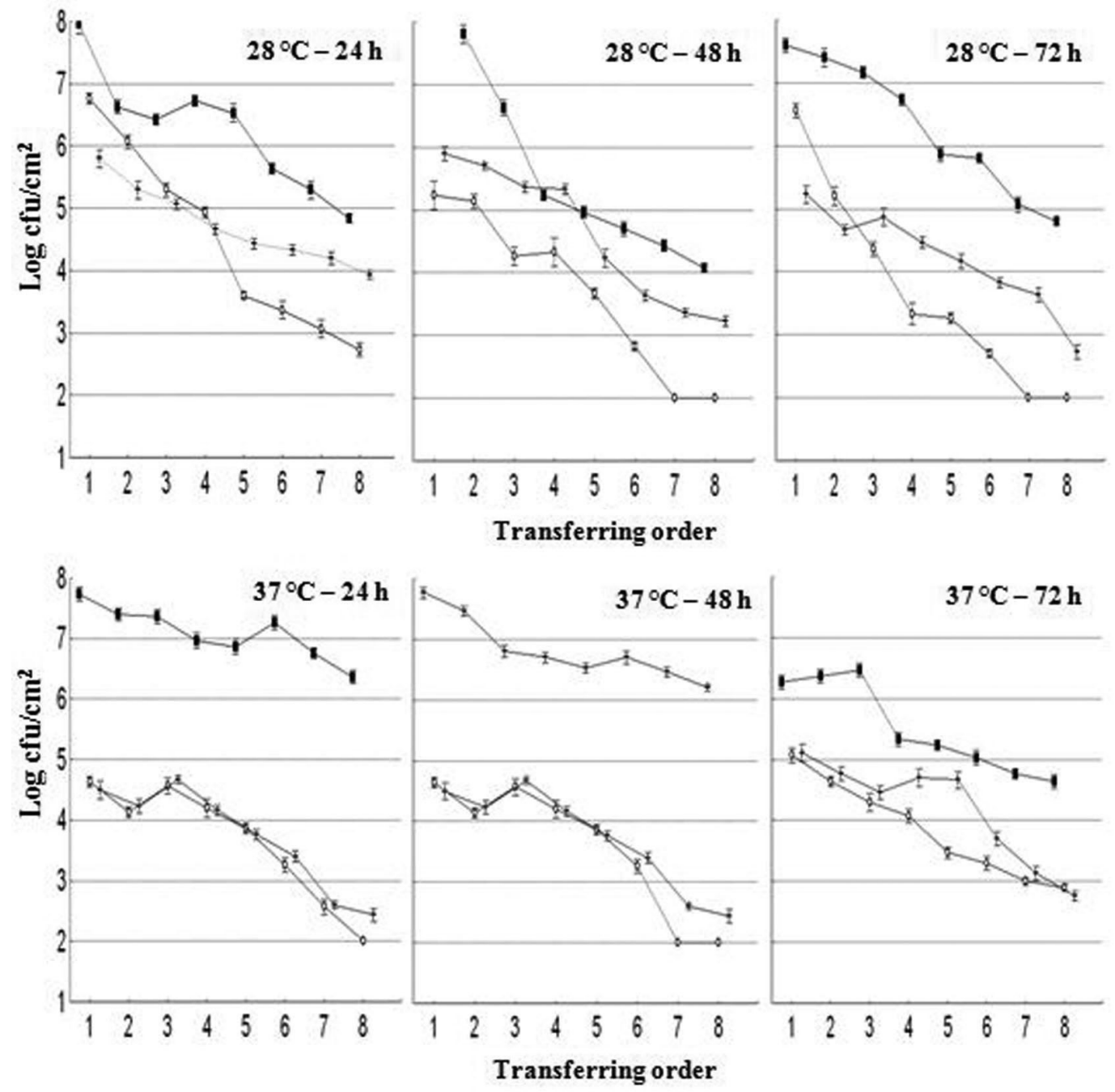

FIGURE 5 - Detachment of $S$. aureus $\mathrm{S} 3$ of stainless steel surfaces as affected by different experimental conditions ( $\mathbf{m}$ : BHI; $\diamond$ : BHI-Glucose; +: BHI-NaCl).

periods (data not showed ). For most experimental conditions, the maximum number of cells (approximately $6 \mathrm{log}$ $\left.\mathrm{cfu} / \mathrm{cm}^{2}\right)$ was found after 6 days of incubation. The bacterial counts indicated biofilm formation on both surfaces under all experimental systems after only 3 days. Greater than $6-7 \log \mathrm{cfu} / \mathrm{cm}^{2}$ of viable cells are needed for biofilm formation, and lower counts could indicate an adhesion process (Planchon et al., 2006).

Counts of $S$. aureus $\mathrm{S} 3$ cells adhered to polypropylene and stainless surfaces before and after application of peracetic acid $(30 \mathrm{mg} / \mathrm{L})$ and sodium hypochlorite are shown in Table I. The decrease in cell counts caused by sodium hypochlorite $(250 \mathrm{mg} / \mathrm{L})$ was $2.6-3.1 \mathrm{Log} \mathrm{cfu} /$ $\mathrm{cm}^{2}$, while for peracetic acid, the decrease was $3.3-4.2$ $\log \mathrm{cfu} / \mathrm{cm}^{2}$. However, in all experimental systems, both sanitizers greatly decreased $(P<0.05)$ the counts of cells adhered to the assayed surfaces. According to the results of these experiments, the sanitizers peracetic acid and sodium hypochlorite, in the concentrations assayed, were not efficient in completely removing the cells of $S$. aureus that had formed biofilms on polypropylene and stainless steel surfaces. Residual cells adhered to the surfaces after the application of sanitizers reinforce the concept of biofilm as a substantial source of cross contamination in food processing plants.

\section{CONCLUSIONS}

The results of this study have clear implications for designing strategies to control cross-contamination in food processing environments because the strains used as test organisms were isolated directly from food-contact surfaces and the assays for adherence and biofilm formation were carried out using surfaces commonly found in food processing plants. The strains assayed here revealed significant abilities to adhere and form biofilms on the as- 
sayed surfaces when exposed to different environmental conditions, suggesting that the clumping phenotype (aggregation) of the tested strains did not show any clear influence of the surrounding environment with regard to the surface type, growth media or temperature of incubation.

\section{REFERENCES}

AMMOR, S.; CHEVALLIER, I.; LAGUE, A.; LABADILE, J.; TALON, R.; DUFOUR, E. Investigation of the selective bactericidal effect of several decontaminating solutions on bacterial biofilms including useful, spoilage and/or pathogenic bacteria. Food Microbiol., v.21, n.1, p.11-17, 2004.

BAGGE-RAVN, D.; GARDSHODN, K.; GRAM, L.; VOGEL, B.F. Comparison of sodium dypochlorite-based foam and peroxyacetic acid-based fog sanitizing procedures in a salmon smokehouse: survival of the general micoflora and Listeria monocytogenes. J. Food Protect., v.66, n.4, p.592598, 2003.

CARSON, C.F.; MEE, B.J.; RILEY, T.V. Mechanism of action of Melalenca alternifolia (Tea tree) oil on Staphylococcus aureus determined by time-kill, lysis, leakage, and salt tolerance assay and electron microscopy. Antimicrob. Agents Chemother., v.46, n.6, p.1914-1920, 2002.

CHAE, M.S.; SCHRAFT, H. Comparative evaluation of adhesion and biofilm formation of different Listeria monocytogenes strains. Int. J. Food Microbiol., v.62, n.1-2, p.103-111, 2000.

CONLON, K.M.; HUMPREYS, H.; O`GARA, J.P. içaR encodes a transcription repressor involved in environmental regulation of ica operon expression and biofilm formation in Staphylococcus epidermidis. J. Bacteriol., v.184, n.16, p.4400-4408, 2002.

FUSTER-VALLS, N.; HERNÁNDEZ-HERRERO, M.; MARÍN-DE-MATEO, M.; RODRÍGUEZ-JEREZ, J.J. Effect of different environmental conditions on the bacterial survival on stainless steel surfaces. Food Control., v.19, n.3, p.308-314, 2008.

HERALD, P.J.; ZOTTOLA, E.A. Scanning electron microscopic examination of Yersinia enterocolitica attached to stainless steel at selected temperature and $\mathrm{pH}$ values. J. Food Prot., v.51, n.6, p.445-448, 1988.
HERRERA, J.J.R.; CABO, M.L.; GONZÁLEZ, A.; PAZOS, I.; PASTORIZA, L. Adhesion and detachment kinectics of several strains of Staphylococcus aureus subsp. aureus under three different experimental conditions. Food Microbiol., v.24, n.6, p.585-591, 2007.

KUNIGK, L.; ALMEIDA, M.C.B. Action of peracetic acid on Escherichia coli and Staphylococcus aureus in suspension or settled on stainless steel surfaces. Braz. J. Microbiol., v.32, n.1, p.38-41, 2001.

KUSUMANINGRU, H.D.; RIBOLDI, G.; HAZELEGER, W.C.; BEUMMER, R.R. Survival of food-borne pathogens on stainless steel surfaces and cross-contamination to foods. Int. J. Food Microbiol., v.85, n.3, p.227-236, 2003.

MARQUES, S.C.; REZENDE, J.G.O.S.; ALVES, L.A.F.; SILVA, B.C.; ALVES, E.; ABREU, L.R.; PICCOLI, R.H. Formation of biofilm by Staphylococcus aureus on stainless steel and glass surfaces and its resistance to some selected chemical sanitizers. Braz. J. Microbiol., v.38, n.3, p.538543, 2007.

MEIRA, Q.G.M.; BARBOSA, I.M.; ATAHAYDE, A.J.A.A.; SIQUEIRA-JÚNIOR, J.P.; SOUZA, E.L. Influence of temperature and surface kind on biofilm formation by Staphylococcus aureus from food-contact surfaces and sensitivity to sanitizers. Food Control., v.25, n.1, p.469$475,2012$.

MORETRO, T.; HERMANSEN, L.; HOLCK, A.L.; SIDHU, M.S.; RUDI, K.; LANGSRUD, S. Biofilm formation and the presence of the intercellular adhesion locus ica among Staphylococci from food and food processing environments. Appl. Environ. Microbiol., v.69, n.9, p.5648-5655, 2003.

MORTON, L.H.G.; GREENWAY, D.I.A.; GAYLARDE, C.C.; SURMAN, S.B. Consideration of some implications of the resistance of biofilms to biocides. Int. Biodeter. Biodegrad., v.41, n.3-4, p.247-259, 1998.

NORMANNO, G.; LA SALANDRA, G.; DAMBROSIO, A.; QUAGLIA, N.C.; CORRENTE, M.; PARISI, A.; SANTAGADA, G.; FIRINU, A.; CIRSETTI, E.; CELANO, G.V. Occurrence, characterization and antimicrobial resistance of enterotoxigenic Staphylococcus aureus isolated from meat and dairy products. Int. J. Food Microbiol., v.115, n.3, p.290-296, 2007. 
PASTORIZA, L.; CABO, M.L.; BERNÁRDEZ, M.; SAMPEDRO, G.; HERRERA, J.R. Combined effects of modified atmosphere packaging and lauric acid on the stability of pre-cooked fish products during refrigerated storage. Eur. Food Res. Technol., v.215, n.3, p.189-193, 2002.

PLANCHON, S.; GAILLARDE-MARTINIE, B.; DORDETFRISONI, E.; BELLON-FONTAINE, M.N.; LEROY, S.; LABADIE, J.; HEBRAUD, M.; TALON, R. Formation of biofilm by Staphylococcus xylosus. Int. J. Food Microbiology, v.109, n.1-2, p.88-96, 2006.
POMPERMAYER, D.M.C.; GAYLARDE, C. The influence of temperature on the adhesion of mixed cultures of Staphylococcus aureus and Escherichia coli to polypropylene. Food Microbiol., v.17, n.4, p.361-165, 2007.

RODE, T.M.; LANGSRUD, S.; HOLCK, A.; MORETRO, T. Different patterns of biofilm formation in Staphylococcus aureus under food-related stress conditions. Int. J. Food Microbiology, v.116, n.3, p.372-383, 2007.

Received for publication on $20^{\text {th }}$ March 2012 Accepted for publication on $13^{\text {th }}$ September 2012 